\title{
MEKANISME SERTIFIKASI GURU DALAM JABATAN DAN KINERJA (Studi Kasus pada SD No 17 Arga Makmur)
}

\author{
Oleh: \\ YUNI INDAH \\ Dosen Prodi Ilmu Administrasi FISIP Universitas Ratu Samban
}

\begin{abstract}
Certification of teachers is an education policy that applied since passed the Law on Teachers and Lecturers No. 14 of 2005. This research discusses the mechanism of certification and post-certification teacher working. This research used a qualitative descriptive approach. Data collected is done by in-depth interviews, obsservasi, methods of visual materials (photographs) and online search. Data analysis was conducted using interactive analysis Miles and Huberman. Based on the research results revealed that the mechanism of certification of teachers in North Bengkulu district has been going well, although still encountered some obstacles in the field. These constraints include: the socialization process in-service teacher still not up to it in view of the false teachers still encountered in filling the Al format. Found 50\% of elementary school in certification of teacher lack participants to have ability on computer information technology and is unable to access the online announcement of certification candidates. Pattern certification portfolio and PLPG considered to have advantages and disadvantages. In general, the performance of elementary school teachers who are already certified educator in SD N NO 17 Argamakmur district, has shown positive changes, although not yet able to satisfy the various parties such as government agencies and private institutions.
\end{abstract}

\section{Keywords: mechanism, certification of teachers in position, performance}

\section{PENDAHULUAN}

Pembentukan konstitusi negara mencantumkan tujuan nasional bangsa Indonesia salah satunya mencerdaskan kehidupan bangsa. Dalam mewujudkan tujuan nasional (mencerdaskan kehidupan bangsa) guru merupakan komponen yang sangat penting. Guru berperan mencerdaskan bangsayang akan mengubah nasib bangsa ini.

Pentingnya peranan guru dapat dilihat dari penelitian Helman dan Loxley yang menunjukkan bahwa keberhasilan pendidikan ditentukan sepertiganya dari guru. Hasil studi Heyneman dan Loxleydi 16 negara berkembang menunjukkan bahwa guru memberikan kontribusi terhadap hasil belajar sebanyak $34 \%$, menejemen $22 \%$, waktu belajar $16 \%$, dan sarana fisik $26 \%$. Pentingnya peranan guru ditegaskan pula oleh Jalal (2007) bahwa pendidikan yang bermutu sangat tergantung pada keberadaan guru yang bermutu yaitu guru yang profesional, sejahtera dan bermartabat.

Muslich (2007) mengatakan bahwa China telah memiliki undang-undang guru sejak 1993, dan peraturan pemerintah yang mengatur kualifikasi guru diberlakukan sejak 2001. Begitu juga di Philipina dan Malaysia belakangan ini telah mempersyaratkan kualifikasi akademik minimun dan standar kompetensi bagi 
guru. Bahkan negara Jepang sudah memberlakukan sertifikasi guru selama 33 tahun (Muslich 2007).

Keberhasilan program peningkatan mutu dan kesejahteraan guru juga dialami oleh Singapura dan Korea Selatan. Di Amerika Serikat, pelaksanaan sertifikasi guru justru berjalan amat lambat. Sebagaimana menurut Jalal (mantan Dirjen PMPTK) bahwa di Amerika Serikat kebijakan sertifikasi bagi guru belum berhasil meningkatkan kualitas kompetensi guru. Hal ini antara lain dikarenakan kuatnya resistensi guru. Sebagai contoh dalam kurun waktu sepuluh tahun, mulai tahun 1997-2006, Amerika Serikat hanya mentargetkan 100.000 guru untuk disertifikasi.

Sebelum kebijakan sertifikasi dilegalkan, baik pemerintah maupun parlemen mengakui bahwa mutu guru di Indonesia tidak begitu memuaskan. Berdasarkan data dari pusat data dan informasi pendidikan, Balitbang Depdiknas, 2004) diketahui bahwa sebanyak 609.217 guru SD tidak memenuhi kualifikasi sebagai guru (tidak layak) dan sebanyak 625.710 guru SD memenuhi kualifikasi sebagai guru (layak). Dari data ini terlihat bahwa 49,33\% dari guru SD di Indonesia tidak memenuhi kualifikasi sebagai guru. Data 2002/2003 tersebut tidak jauh berbeda dengan data di tahun 2004. Hal ini dapat dilihat dari data dari Direktorat Tenaga Kependidikan Dikdasmen Depdiknas (dalam Muslich, 2007) tahun 2004 menunjukkan terdapat $991.243(45,96 \%)$ guru SD, SMP, dan SMA yang tidak memenuhi kualifikasi pendidikan minimal. Dari data di tahun 2004 dan 2006 dapat diambil kesimpulan terdapat kenaikan jumlah guru yang memenuhi kualifikasi guru hanya 3,99\%. Angka 3,99\% merupakan suatu kenaikan yang tidak signifikan.
Data Kompas menyebutkan bahwa mayoritas guru Indonesia tidak memenuhi kualifikasi sebagai guru. Pada umumnya tingkat pendidikan guru SD masih setara dengan D2, sedangkan UU 14/2005 mensyaratkan bahwa tingkat pendidikan guru SD harus S1 atau D4. Data resmi dari Depdiknas menunjukkan bahwa hanya sekitar 35\% guru Indonesia dari total 2,7 juta guru yang berpendidikan S1, dan guru SD yang berpendidikan S1 hanya sekitar 10\% (Kompas, 2006).

Pelaksanaan sertifikasi guru di Indonesia telah dimulai sejak 2006. Depdiknas mentargetkan agar pada tahun 2015 nanti semua guru sudah tersertifikasi dan sudah memenuhi kualifikasi yang disyaratkan dalam UU No 14 tahun 2004. Guru di Bengkulu Utara yang sudah disertifikasi sebesar $47 \%$ dari total guru. Hal ini dapat dilihat dalam tabel berikut ini.Berdasarkan data Dinas Pendidikan dan Kebudayaan Kabupaten Bengkulu Utara Tahun 2013diketahui bahwa di tahun 2012, sebanyak 1666 guru (60.95\%) guru di Kabupaten Bengkulu Utara sudah disertifikasi. Persentase terkecil guru yang sudah disertifikasi terdapat pada satuan pendidikan SMA/SMK yaitu sebesar $0,41 \%$ guru, diikuti dengan satuan pendidikan TK yang sudah disertifikasi sebesar 38.36, SD sebesar $63.85 \%$, satuan pendidikan SMP sebesar $70.89 \%$ guru yang sudah disertifikasi. Persentasi terbesar guru yang sudah disertifikasi ada pada satuan pendidikan SMP yaitu sebesar $70.89 \%$.

Sejak awal implementasi kebijakan sertifikasi muncul berbagai opini mengenai kebijakan ini seperti dilansir oleh Majalah Pendidikan "Media Sekolah" (2011) bahwa hasil penelitian Depdiknas, sertifikasi yang dilakukan melalui penilaian portofolio sejak tahun 2005 lalu tidak memberikan dampak besar terhadap perubahan kultur di sekolah. Sistem portofolio menuai masalah, pada proses 
pengumpulan dokumen yang dibutuhkan sebagaì syarat penilaian guru mengalami kemiskinan dokumen keprofesian lantaran akses kesejarahan profesi guru buruk. Perburuan sertifikat terjadi di setiap acara ilmiah seperti seminar. Persoalan lain adalah terkait dengan uji validìtas dokumen yang menyangkut konsistensi bukti fisik dengan realitas kinerja.

Berdasarkan hasil monitoring dan evaluasi penyelenggaraan sertifikasi guru tahun 2007 dan 2008, yang dilakukan oleh Departemen PendidikanNasional dalam situs Depdiknas khususnya untuk penyelenggaraan sertifikasi guru melalui penilaian portofolio masih ditemukan sejumlah kendala yang dapat menghambat proses pelaksanaan sertifikasi.Salah satunya tidak sinkronnya data dengan bukti-bukfti fisik. Ditemui masih banyak bukti-bukti fisik yang janggal dan diragukan keabsahannya.

Dari latar belakang di atas peneliti ingin meneliti bagaimana mekanisme sertifikasi di Kabupaten Bengkulu Utara di setiap tahapnya. Kendala apa yang ditemui di setiap tahap dan mengapa kendala itu bisa terjadi serta langkah apa yang diambil untuk mengatasi kendala tersebut. Akhir dari analisis ini akan keluar rekomendasi kebijakan. Selain itu penelitian ini juga mengungkap bagaimana kinerja guru pasca sertifikasi, apakah ada perubahan ke arah lebih baik atau stagnant.

\section{METODE PENELITIAN}

Penelitian ini menggunakan metode kualitatif dengan desain deskriptif kualitatif studi kasus. Penelitian dilakukan SD N No 17 Argamakmur Teknik penentukan informan melalui snowballing sampling dan key persons. Metode pengumpulan data yang digunakan dalam penelitian ini adalah metode wawancara mendalam, Focus Group Discussion (FGD) pada kelompok guruguru yang sudah mendapat sertifikasi, metode observasi, dan metode penelusuran data online. Aspek yang diteliti adalah mekanisme sertifikasi guru dalam jabatan dan kinerja guru.

Hasil penelitian akan dianalisis dengan menggunakan metode analisis deskriptif kualitatif. Langkah analisis data yang digunakan dalam penelitian ini adalah Interactive ModelAnalysis dari Miles dan Huberman. Untuk keperluan validitas data, penulis menggunakan teknik triangulasi.

\section{HASIL DAN PEMBAHASAN}

1. Mekanisme Sertifikasi Berdasarkan Alur Kegiatan Guru

Implementasi kebijakan sertifikasi guru dalam jabatan di Kabupaten Bengkulu Utara dapat dilihat mekanisme kegiatan yang dilalui oleh guru sertifikasi. Proses tersebut dimulai dari sosialisasi sampai dengan diterimannya tunjangan profesi. Ditambahkan pula oleh peneliti bagaimana kebijakan pemantaun pasca guru menerima tunjangan profesi.

Sosialisasi sertifikasi guru dilakukan oleh Dinas Pendidikan dan Kebudayaan setiap tahun. Tidak ada kesulitan yang berarti saat mengadakan kegiatan ini karena dilakukan melalui kerja sama yang baik. Tidak ada dana khusus yang dialokasikan untuk kegiatan sosialisasi.Materi yang disampaikan jelas dan tidak membinggungkan. Materi sosialisasi disampaikan melalui media kaset CD (Compact Disk).

Setelah sosialisasi dilakukan, maka Dinas Pendidikan dan Kebudayaan melakukan mendataan guru-guru yang hendak diusulkan dalam sertifikasi. Proses penetapan peserta merupakan kegiatan terpenting dalam pelaksanaan sertifikasi guru. Apabila terjadi kesalahan atau ketidakadilan dalam penetapan peserta oleh Dinas Pendidikan dan Kebudayaan, maka tidak menutup kemungkinan akan terjadi aksi ketidakpuasan dari para guru. 
Untuk mengantisipasi hal tersebut, dalam menetapkan guru peserta sertifikasi Dinas Kabupaten Bengkulu Utara dengan mempertimbangkan kriteria masa kerja/pengalaman kerja, usia, pangkat/golongan, beban mengajar, Jabatan/tugas tambahan, prestasi kerja.

Meski banyak rumor yang mengatakan jika ingin masuk kuota guru dapat mengunakan grativikasi atau "sogok", Jasman selaku Kepala Bagian TK/SD Dinas Pendidikan dan Kebudayaan Kabupaten Bengkulu Utara membantah rumor tersebut. "Tidak ada permainan..!!" ujar Jasman dengan tegas. Fenomena perekrutan yang dilakukan secara objektif dan transparan juga katakan oleh kedelapan informan. Kedelapan informan di SD Negeri 17 Argamakmur tidak mengeluarkan sejumlah uang agar namanya dapat masuk dalam daftar nama peserta sertifikasi. Kedelapan informan mengatakan bahwa penjaringan calon peserta sertifikasi guru dalam jabatan ini sudah dilakukan secara objektif dan transparan, hal ini dibuktikan dengan mengumumkan secara terbuka guru-guru yang dapat mengikuti sertifikasi. Pengumuman terbuka ini dilakukan agar publik dapat mengetahui siapa yang dapat mengikuti sertifikasi pada tahun tersebut dan siapa yang berhak mengikuti sertifikasi

Dari data yang diperoleh dari Dinas Pendidikan dan Kebudayaan Kabupaten BengkuluUtara belum ada guru yang disertifikasi melalui proses PSPL (Pemberian Sertifikat Pendidik secara Langsung). Dari 1057 guru SD yang sudah disertifikasi semua melalui proses portofolio dan PLPG. Berkaitan dengan pola sertifikasi di tahun 2012, diatur dalam Permendikan No 5 tahun 2005 pasal 2.

Kelebihan portofolio adalah lebih menghargai jejak pretasi guru yang dilakukan. Kekurangannya adalah dalam proses portofolio ditemui indikasi pemalsuan dokumen. Keharusan melampirkan dokumen asli dirasa memberatkan guru karena guru kesulitan mencari dokumen asli. Kondisi ini memunculkan pihak-pihak oportunis yang menawarkan jasa pembuatan sertifikat.

Dari pendapat informan pokok dan informan ahli dapat disimpulkan bahwa Pola PLPG dinilai lebih memiliki dampak yang besar dalam proses pembelajaran di kelas daripada pola portofolio. Guru muda dan enerjik dapat menerapkan metode pembelajaran baru yaitu PAIKEM (Pembelajaran aktif inovatif dan menyenangkan).

Kekurangan PLPG adalah kelulusan guru sertifikasi melalui pola PLPG lebih mudah dan bagi peserta PLPG di atas 50 tahun penilaian banyak dipengaruhi unsur kemanusiaan, sehingga sertifikasi diberikan berdasarkan faktor kasihan.Untuk guru dalam jabatan yang sudah tergolong senior (memiliki masa kerja 20 tahun) sulit untuk merubah pola mengajar dengan metode lama. Pola PLPG untuk guru senior tidak begitu berdampak pada proses pembelajaran karena mereka telah terpola mengajar bertahun-tahun mengunakan metode lama.

Meski belum ditemukan pola sertifikasi yang tepat, penulis menelusuri tanggapan informan pokok tentang pola sertifikasi yang tepat dan bermanfaat bagi diri informan. Data primer menunjukkan bahwa sebanyak tujuh informan (90\%) memilih pola PLPG sebagai pola yang tepat untuk diterapkan karena informan merasakan dampak positif pada diri informan. Informan memperoleh banyak pengetahuan tentang pembelajaran yang aktif, inovatif dan menyenangkan. Satu informan $(10 \%)$ mengatakan bahwa pola yang paling tepat diterapkan adalah pola portofolio diikuti dengan pola PLPG.

Berkaitan dengan waktu penyusunan portofolio, walaupun dengan waktu yang minim namun guru-guru dapat 
menyelesaikan penyusunan portofolio. Setelah guru selesai menyusun portofolio, maka portofolio diserahkan ke Dinas Pendidikan dan Kebudayaan Bengkulu Utara. Dari Dinas Pendidikan dan Kebudayaan Bengkulu Utara diserahkan ke LPMP Bengkulu untuk dikirim ke LPTK sesuai dengan program studi. Hampir semua informan menyatakan tidak dikenakan biaya administrasi atau istilah populer di media massa adalah "pungli" (pungutan liar).

Dari jawaban informan pokok dan informan kunci di atas disimpulkan penilaian portofolio telah dilakukan dengan objektif. Tidak ada celah untuk melakukan gratifikasi. Hal ini dikarenakan asesor tidak mengetahui guru yang dinilai portofolionya. Selain itu dokumen portofolio diperiksa di ruang khusus dan dokumen tidak boleh di bawa pulang. Untuk menjamin kualitas penilaian portofolio setiap asesor diberi jatah maksimal 50 portofolio. Proses penilaian portofolio telah mengikuti prinsip objektif dan adil.

Setelah guru dinyatakan lulus dan menerima sertifikat pendidik. Tahap selanjutnya adalah proses penyaluran tunjangan profesi. Kendala yang Ditemui dalam Penyaluran Tunjangan Profesi diantaranya: tidak sesuainya tunjangan profesi dengan pokok gaji, keterlambatan pembayaran tunjangan profesi, sulitnya akses guru honorer di daerah untuk memperoleh SK inpassing

Setelah guru menerima sertifikasi maka dilakukan monitoring. Dari fakta hasil penelitian sangat disayangkan guru yang dipantau oleh Dinas Pendidikan dan Kebudayaan adalah guru SD yang berada perkotaan. Jasman menjelaskan kondisi ini berkaitan dengan masalah dana. Tidak ada dana khusus untuk pemantauan/monitoring. Monitoring guru sertifikasi di Kabupaten Bengkulu Utara menggunakan lembar instrumen pemantauan guru yang bersertifikasi. Lembar instumen terlampir. Dalam instumen tersebut guru harus membuat 27 perangkat administrasi mengajar.

Berdasarkan observasi, kedelapan informan mengeluhkan beratnya membuat 27 perangkat administrasi guru kelas tersebut. Terlihat di wajah kelelahan karena mereka harus lembur baik di sekolah dan dilanjutkan di rumah. Beban kerja guru 24 jam/minggu ditambah guru harus membuat perangkat administrasi pembelajaran membuat informan kelelahan. Dari observasi peneliti terhadap instrumen itu masih ditemui beberapa kejanggalan:

1. Beberapa format masih membinggungkan. Misalnya buku informasi penilaian dan daftar nilai, buku pelaksanaan harian dengan agenda harian. Isinya dari kedua format itu sebenarnya sama, tapi mengapa harus dibuat dalam format yang berbeda.

2. ada item dari perangkat adminstrasi yang sulit diterapkan di sekolah dasar. Seperti buku ulangan bergilir, sangat sulit diterapkan di SD terutama untuk kelas rendah.

3. melihat kondisi sekolah ada, seperti di SD N 17 Argamakmur, sistem pembelajaran tidak mengunakan guru kelas tapi guru bidang studi, dan memiliki guru BK (bimbingan konseling). Ada item laporan penilaian ahlak dan kepribadian, yang memiliki data tersebut jelas guru BK dan bukan guru bidang studi.

Dari berbagai masalah di atas, Snr selaku penguru KKG gugus 1 mengatakan bahwa dalam KKG akan dibahas beberapa format yang membinggungkan.

Pada tanggal 18 Februari 2013 dilakukan supervisi guru-guru sertifikasi. Di SD N 17 Argamakmur. Supervisi dilakukan oleh pengawas sekolah. Berdasarkan FGD (Focus Group Discussion) tanggal 28 Februari JW 
(pengawas) mengatakan bahwa supervisi dilakukan untuk menilai kinerja guru yang sudah bersertifikasi dan sebagai bahan pemetaan LPMP.

Ditahun 2011 ini Dirjen PMPTK membentuk UPM (Unit Pelayanan Masyarakat). UPM berfungsi sebagai pusat informasi umum tentang pelaksanaan sertifikasi guru, mediator antara masyarakat dan guru dengan penyelenggara sertifikasi guru, pusat pelayanan masyarakat (internal dan eksternal) tentang pelaksanaan sertifikasi guru. Keberadaan UPM sebenarnya sangat penting untuk memonitor proses implementasi kebijakan sertifikasi, namun sangat disayangkan dirjen PMPTK selaku lembaga yang membentuk UPM belum mensosialisasikan keberadaan lembaga ini secara maksimal.

\section{Sertifikasi dan Kinerja Guru}

Sertifikasi guru dalam jabatan adalah kebijakan pemberian sertifikat pendidik kepada guru yang masih aktif mengajar (on the job) yang diatur dalam Undang-undang Nomor 14 tahun 2005. Undang-undang No 14 tahun 2005 tentang guru dan dosen .Seyogyanya guru yang sudah lulus sertifikasi menunjukkan adanya perubahan kinerja ke arah yang lebih baik. Kinerja adalah fungsi dari aspek kemampuan (ability), aspek psikologis (persepsi dan sikap) dan kesempatan (Opportunity). Kinerja guru adalah wujud perilaku guru yang merupakan akumulasi dari fungsi aspek individu (kompetensi), aspek psikologis dan aspek organisasi yang dimiliki guru dalam menjalankan tugas-tugas pokoknya(lihat Gibson, Mitchel, dkk, 2007).

Kemampuan mengelola pembelajaran tersebut menyangkut tiga fungsi manajerial yaitu: perencanaan, pelaksanaan dan pengendalian(lihat Mulyasa, 2009). Hasil observasi menunjukkan bahwa perangkat kedelapan guru yang menjadi informan pokok dalam penelitian ini sudah menunjukkan perangkat administrasi yang baik. Rencana Pelaksanaan Pembelajaran (RPP) yang mereka buat telah menunjukkan adanya perubahan ke arah RPP berkarakter. Di sekolah tempat tugas informan telah memiliki media pembelajaran berbasis teknologi komputer sehingga informan telah menerapkan pembelajaran berbasik TIK (Teknologi Informasi Komputer) dan PAIKEM (Pembelajaran Aktif Inovatif Kreatif dan Menyenangkan).Dalam hal penggunaan media dan sumber pembelajaran guru SD 17 Argamakmur sudah dapat mengunakan dan memanfaatkan media yang berbasis komputer.

Kegiatan pengembangan dan peningkatan kualitas profesi adalah kegiatan-kegiatan yang dapat meningkatkan penetahuan dan kemampuan mengajar guru seperti seminar, KKG (Kelompok Kerja Guru). Dalam hal pengembangan dan peningkatan kualitas profesi guru, di Kabupaten Bengkulu telah dibentuk KKG khusus untuk guru sertifikasi.

Selain aspek kompetensi, kinerja juga dipengaruhi oleh aspek psikologis individu. Salah satu aspek psikologis adalah faktor kepuasan kerja. kepuasan kerja adalah perasaan pegawai tentang menyenangkan atau tidak pekerjaan mereka. Kepuasan kerja merujuk pada harapan seseorang dengan imbalan yang disediakan pekerjaan,sehingga kepuasan kerja berkaitan dengan aspek psikologis(lihat Vromm dalam Muhammad, 2008:36)

Kedelapan informan menyatakan perasaan bahagia dan kebangaan sebagai guru sekolah dasar semakin bertambah setelah mereka menerima sertifikasi. Dari fakta ini maka disimpulkan bahwa sertifikasi dapat meningkatkan harkat 
derajat dan martabat guru dalam pandangan masyarakat.

Kedelapan informan di SD N 17Argamakmur yang telah memperoleh tunjangan profesi telah mempunyai laptop dan notebook untuk menunjang pengembangan profesi sebagai guru. Dengan laptop ini guru dapat membuat perangkat administrasi dan mengajar dengan berbasis pada ICT.

Kinerja guru bersertifikasi juga dapat dilihat dari frekuensi mereka dalam mengikuti kegiatan seperti diklat, workshop dan seminar. Data primer penelitian menunjukkan bahwa guru-guru di SDN 17 Argamakmur berusaha meningkatkan profesionalitas diri mereka sebagai guru.

Aspek organisasi dapat dilihat dari sumber daya dan kepemimpinandan faktor kesempatan. sumber daya adalah energi pengerak seperti sumber daya manusia yang produktif. Kepemimpinan menyangkut peran kepala sekolah dalam mendinamisasikan bawahannya yaitu guru dan staf.

Stmengatakan evaluasi kinerja penting dilakukan untuk mengetahui seberapa besar nilai kerja yang sudah guru dan staf lakukan dan apa yang seharusnya guru dan staf lakukan kedepan. Hasil dari evaluasi kinerja kepala sekolah terhadap 8 guru yang sudah sertifikasi menyebutkan bahwa kedelapan informan memiliki kinerja yang lebih baik dari sebelumnya. Informan menjadi lebih rajin dalam menlengkapi administrasi pendidikan dan lebih termotivasi dalam mengajar.

Jika nilai kinerja yang diberikan kepala sekolah SD N 17 terhadap delapan informan adalah 80 berbeda dengan nilai kinerja yang dilakukan pengawas sekolah. Pada tanggal 18 Februari 2013 dilakukan supervisi guru-guru sertifikasi, Dari hasil supervisi tersebut diketahui bahwa pada 8 guru yang sudah disertifikasi di SD N 17 Argamakmur menghasilkan bahwa rata- rata dalam pelaksanaan pembelajaran sudah baik. Nilai rata-rata guru SD N 17 Argamakmur adalah 78.

Nilai kinerja rata-rata di kepala sekolah dan pengawas sekolah adalah 79 . Nilai ini sangat jauh berbeda dengan nilai uji kompetensi secara on line. Pada tanggal 6 Agustus 2012, kedelapan guru sertifikasi mengikuti UK (Uji Kompetensi) secara on line. Dalam kegiatan UK guru menjawab soal yang berkaitan dengan profesi dan pedagogik. Hasil dari nilai UK ke delapan guru rata-rata mendapatkan nilai 55. Nilai 55 dinilai masih minim sekali jika dibandingkan dengan nilai passing grade yang ditetapkan oleh Depdiknas yaitu 70.Dari hasil penilaian kinerja praktik mengajar guru-guru memperoleh nilai baik (78). Nilai ini cukup baik namun nilai ujian secara tertulis cukup memprihatinkan nilai rata-rata yang diperoleh adalah 55 . Hal ini dapat disimpulkan bahwa dalam implementasi pembelajaran guru-guru telah baik namun ketika diuji secara kognitif hasilnya masih di bawah standar (passing grade 70).

\section{PENUTUP}

\section{Kesimpulan}

Mekanisme sertifikasi guru dalam jabatan di kabupaten Bengkulu Utara telah dilaksanakan dengan baik walaupun masih ditemui beberapa kendala-kendala di lapangan.

Secara umum kinerja guru SD N 17 Argamakmur yang sudah bersertifikat pendidik telah menunjukkan perubahan positif meski belum dapat memuaskan berbagai pihak seperti lembaga pemerintah dan lembaga swasta (dewan pendidikan).

\section{Saran}

Perlu adanya pemantauan guru sertifikasi secara terpadu dan berkala. Pemantauan dilakukan secara merata. 
Pemantauan perlu disupport pendanaan dari Pemerintah Daerah sehingga proses pemantauan dapat dilakukan secara maksimal.

Dalam pembayaran tunjangan profesi, guru harus memperoleh hak tunjangan profesi sepenuhnya yaitu sesuai dengan gaji pokok dan dalam setahun harus dibayarkan 12 bulan tanpa tertunda.

Instrumen pemantauan guru sertifikasi perlu disederhanakan sehingga tidak memberatkan guru.27 insturmen adminsitrasi guru kelas bagi guru sertifikasi ditambah beban kerja guru 24 jam/minggu cukup membuat kelelahan bagi guru maka beban kerja guru 24 jam/minggu untuk guru kelas dikaji ulang, misalnya dengan memasukkan tugas wali kelas sebagai salah satu bentuk beban kerja guru

Idealnya guru yang dinyatakan lulus sertifikasi adalah guru yang sebelumnya sudah profesional. Bukan keprofesionalan hasil Diklat dan bukan pula sebaliknya keprofesionalan yang diraih dengan jalan pintas atau dengan cara yang tidak profesional, sehingga uji sertifikasi lebih memiliki makna bukan sebagai kesempatan mendapatkan sesuatu tetapi sebagai pengakuan atas pengalaman profesional guru. Dengan demikian, maka perjuangan yang paling bukan meraih sesuatu dari sertifikasi tetapi mempertahankan dan meningkatkan kualitas sebagai guru profesional.

\section{DAFTAR PUSTAKA}

\section{Buku}

Arikunto, Suharsimi. (2002). Prosedur Penelitian, Suatu Pendekatan Praktek, Edisi Revisi. Jakarta: VIRhineka Cipta.

Bungin Burhan. (2009). Penelitian Kualitatif, Komunikasi, Ekonomi, Kebijakan Publik, dan Ilmu Sosial Lainnya. Jakarta: PT Fajar Interpratama Offset.
Mulyana, Deddy. (2008). Pengantar Ilmu Komunikasi. Bandung: PT Rosda. Muhammad, Fadel. (2008). Reinventing Local Government, Pengalaman Dari Daerah. Jakarta: PT. Elex Media Komputindo.

Moleong, J Lexy. (2009). Metode Penelitian Kualitatif, Edisi Revisi. Bandung: PT Rosda Karya.

Muslich, Masnur. (2007). Sertifikasi Guru Menuju Profesionalisme Pendidik. Jakarta: PT Bumi Aksara.

Mulyasa. (2009). Standar Kompetensi dan Sertifikasi Guru. Bandung: PT Remaja Rosdakarya.

Nugroho, Riant. (2010). Public Policy, Dinamika Kebijakan-Analisis Kebijakan-Manajemen Kebijakan. Jakarta: PT Elex Media Komputindo.

Nawawi, Ismail. (2007). Public Policy, Analisis, Strategi Advokasi Teori dan Praktek. Surabaya: PNM.

Parson, Wayne. (2006). Public Policy Pengantar Teori dan Praktek, Analisis Kebijakan. Jakarta: Kencana.

Suharto, Edi. (2010). Analisis Kebijakan Publik, Panduan Praktis Mengkaji Masalah Sosial. Bandung: CV Alpabetha Bandung.

Wahyono, Iman. (2010). Perilaku Organisasi. Yogyakarta: Graha Ilmu.

\section{Hasil Penelitian}

Nova Aris Setiawan. (2008). Implementasi Kebijakan Sertifikasi Guru Sekolah Dasar di Kabupaten Kudus.

Mulyono. (2009). Implementasi Kebijakan Sertifikasi Guru Sekolah Dasar di Kabupaten Kudus.

\section{Dokumen}

Balitbang Depdiknas 2004, Pusat Data dan Informasi 
Direktorat Jenderal Peningkatan Mutu Pendidik dan Tenaga Kependidikan (Ditendik PMTK), 2008, Penilaian Kinerja Guru

Buku Panduan Sertifikasi Tahun 2009, Dinas Pendidikan Nasional Kabupaten Bengkulu Utara

Buku 1 Pedoman Penetapan Peserta Sertifikasi Guru Dalam Jabatan Tahun 2011
Buku modul Sertifikasi Guru Dalam Jabatan Depdiknas Rayon 3 UNIB Tahun 2009

Buku Pedoman penyaluran tunjangan profesi melalui dana desonsentrasi yang diterbitkan oleh Direktorat Profesi Pendidik dan Direktoran Jenderal Peningkatan Mutu Pendidik dan Tenaga Kependidikan

Buku 2 Pedoman Pelaksanaan Penilaian Kinerja Guru Kemendiknas 